\title{
PENGATURAN SANKSI PIDANA MATI BAGI PELAKU TINDAK PIDANA KORUPSI DI WAKTU BENCANA ALAM
}

\author{
Muhammad Rosikhu ${ }^{1}$, Johan Rahmatulloh ${ }^{2}$ \\ 1,2,Universitas Bumigora, Jl. Ismail Marzuki No.22, Kota Mataram, Nusa Tenggara Barat. 83127 \\ rosikhu@universitasbumigora.ac.id,johan.rahmatulloh@gmail.com
}

\begin{abstract}
Abstrak
Tujuan penelitian ini adalah untuk mengetahui dan menganalisis pengertian bencana alam nasional dan penegakan hukuman pidana mati menurut pasal 2 ayat 2 Undang-undang Nomor 20 Tahun 2001 tentang Perubahan Atas Undang-undang Nomor 31 Tahun 1999 tentang Pemberantasan Tindak Pidana Korupsi. Permasalahan dalam penelitian ini adlah karena ketidakjelasan frasa bencana alam nasional sehingga berpotensi tidak diterapkannya hukuman maksimal bagi pelaku tindak pidana korupsi. Pendekatan yang digunakan ada dua yaitu pendekatan peraturan perundang-undangan dan pendekatan konseptual. Dalam penelitian ini dihasilkan bahwa secara terminologis, pengertian bencana alam nasional tidak diatur sama sekali di dalam peraturan perundang-undangan melainkan hanya syarat-syarat untuk dapat ditetapkan menjadi bencana alam nasional. Selanjutnya, pengaturan sanksi pidana mati dalam undangundang tersebut tidak lebih sebagai pasal untuk menakuti para pelaku. Maka dari itu, pemerintah perlu mengatur batas minimum dan maksimum uang yang dikorupsi untuk pengenaan sanksi pidana mati serta penegak hukum diperlukan komitmen untuk menerapkan sanksi maksimal tersebut di waktu bencana alam.
\end{abstract}

Kata Kunci: Pidana Mati; Bencana Alam Nasional; Tindak Pidana Korupsi.

\begin{abstract}
The purpose of this study is to determine and analyze the meaning of national natural disasters and the enforcement of the death penalty according to Article 2 paragraph 2 of Law Number 20 of 2001 concerning Amendments to Law Number 31 of 1999 concerning the Eradication of Corruption. The problem in this research is that the phrase national natural disaster is not clear, so it has the potential not to apply the maximum penalty for perpetrators of criminal acts of corruption. There are two approaches used, namely the statutory approach and the conceptual approach. In this study, it was concluded that in terms of terminology, the notion of a national natural disaster is not regulated at all in the laws and regulations but only the requirements to be declared a national natural disaster. And next, the regulation of capital punishment in the law is nothing more than an article to frighten the perpetrators. Therefore, the government needs to make regulate the minimum and maximum limits for the money that is corrupted for the imposition of capital punishment and law enforcement requires a commitment to apply the maximum sanctions during natural disasters.
\end{abstract}

Keywords: Death Penalty; National Natural Disaster; Corruption Crime. 


\section{PENDAHULUAN}

\section{LatarBelakang}

Kasus operasi tangkap tangan (OTT) yang dilakukan oleh Tim Kejaksaan Negeri Mataram terhadap oknum anggota DPRD Kota Mataram, Kepala Dinas Pendidikan Kota Mataram dan oknum PNS Dinas Pendidikan Kota Mataram. Penangkapan orang-orang tersebut diduga terkait dengan penyusunan dan pembahasan rencana Anggaran Pendapatan dan Belanja Kota Mataram (APBD-P) 2018 yang digunakan untuk tahap rekonstruksi dan restorasi beberapa gedung sekolah di Kota Mataram, yang mengalami kerusakan akibat bencana alam gempa bumi yang melanda Provinsi Nusa Tenggara Barat. ${ }^{1}$

Tindakan para oknum tersebut mendapat tanggapan dari pegiat anti korupsi Johan Rahmatulloh dari lembaga Solidaritas Masyarakat untuk Transparansi Nusa Tenggara Barat (SOMASI NTB). Menurut Johan Rahmatulloh bahwa Kejaksaan Negeri Mataram diharapkan dapat menerapkan hukuman yang maksimal berupa hukuman

\footnotetext{
${ }^{1}$ Nilai anggaran untuk rehabilitasi bangunan SD dan SMP tersebut sebesar Rp 4,2 Miliar. Dengan modus memuluskan alokasi anggaran tersebut, Muhir meminta uang kepada Kepala Dinas Pendidikan Kota Mataram H Sudenom. Lihat, Suharli. (2018), Ditangkap di Depan Anak, Sabtu, 15 September 2018, hlm. 1 dan 4. Lihat juga pada, Liputan 6.com. (2018), Petugas Intai Muhir Selama 2 Bulan Terkait Korupsi Pembangunan Sekolah di Lombok,

https://www.liputan6.com/news/read/3645799/petuga s-intai-muhir-selama-2-pekan-terkait-korupsipembangunan-sekolah-di-lombok. 17 september 2018, Diakses tanggal 25 juni 2021, Zulfikar, Satria. (2018). Minta Jatah Uang Rehab Gempa Loombok Politikus Golkar Ditangkap. https://www.viva.co.id/berita/nasional/1074726-mintajatah-uang-rehab-gempa-lombok-politikus-golkarditangkap. 14 September 2018, Diakses tanggal 25 juni 2021.
}

mati atau hukuman seumur hidup kepada oknum anggota legislatif tersebut. Penerapan sanksi hukum maksimal tersebut karena dilakukan pada waktu (tempos) bencana alam sesuai dengan ketentuan Pasal 2 ayat 2 Undang-undang Republik Indonesia Nomor 20 Tahun 2001 tentang Perubahan Atas Undang-undang Republik Indonesia Nomor 31 Tahun 1999 tentang Pemberantasan Tindak Pidana Korupsi, selanjutnya disingkat UU Tipikor. ${ }^{2}$

Ditegaskan dalam Pasal 2 UU Tipikor secara lengkap disebutkan:

(1) Setiap orang yang secara melawan hukum melakukan perbuatan memperkaya diri sendiri atau orang lain atau suatu korporasi yang dapat merugikan keuangan negara atau perekonomian negara, dipidana dengan pidana penjara seumur hidup atau pidana penjara paling singkat 4 (empat) tahun dan paling lama 20 (dua puluh) tahun dan denda paling sedikit Rp 200.000.000,00 (dua ratus juta rupiah) dan paling banyak $\mathrm{Rp}$ 1.000.000.000,00 (satu miliyar rupiah).

(2) Dalam hal tindak pidana korupsi sebagaimana dimaksud dalam ayat (1) dilakukan dalam keadaan tertentu, pidana mati dapat dijatuhkan.

Dalam penjelasan Pasal 2 ayat 2 UU Tipikor, yang dimaksud dengan keadaan tertentu adalah:

\footnotetext{
${ }^{2}$ Rahmatulloh, Johan. (2018) HM Terancam Dicoret dari Daftar Bacaleg, Suara NTB, 15 September 2018, hlm. 15. Wawancara dilakukan pada tanggal 14 September 2018 oleh Haris Makhtul.
} 
"Keadaan yang dapat dijadikan alasan pemberatan pidana bagi pelaku tindak pidana korupsi yaitu apabila tindak pidana tersebut dilakukan terhadap dana-dana yang diperuntukkan bagi penanggulangan keadaan bahaya, bencana alam nasional, penanggulangan akibat kerusuhan sosial yang meluas, penanggulangan krisis ekonomi dan moneter, dan pengulangan tindak pidana korupsi".

Pendapat yang berbeda dikemukakan oleh Ketut Sumedana sebagai Kepala Kejaksaan Negeri Mataram yang mengatakan bahwa "Karena gempa bumi yang terjadi di Nusa Tenggara Barat, khususnya Lombok, bukan merupakan bencana alam nasional menurut Pasal 2 ayat 2 Konvensi, maka oknum anggota Dewan tidak dapat dipidana mati sesuai dengan ketentuan Pasal 2 ayat 2 UU Tipikor. ${ }^{3}$ Akan tetapi, itu nanti bisa menjadi unsur pemberat tuntutan..."4

Dalam hal ketentuan keadaan tertentu "bencana alam nasional" menimbulkan penafsiran yang berbeda. Berdasarkan perbedaan pendapat tersebut, Penulis beramsusi ketentuan "bencana alam nasional" tersebut merupakan menjadi suatu kajian yang menarik untuk dilakukan sebuah penelitian yang berjudul "Pengaturan Sanksi Pidana Mati Bagi Pelaku Tindak Pidana Korupsi Di Waktu Bencana Alam".

\footnotetext{
${ }^{3}$ Sumedana, Ketut. (2018). Muhir Lolos dari Ancaman Hukuman Mati, Lombok Post, 19 September 2018, hlm. 27.

${ }^{4}$ Suharli. (2018). Jaksa Beberkan Dosa Muhir, Lombok Post, 17 Oktober 2018, hlm. 11.
}

\section{Rumusan Masalah}

Berdasarkan uraian dalam pendahuluan di atas difokuskan penelitian dengan permasalahan sebagai berikut:

1. Apa makna 'Bencana Alam Nasional' yang diatur dalam penjelasan Pasal 2 ayat 2 UU Tipikor?

2. Bagaimana pengaturan penegakan sanksi pidana mati bagi para pelaku tindak pidana korupsi di waktu bencana alam nasional dalam penjelasan pasal 2 ayat 2 ?

\section{Metode Penelitian}

1. Jenis Penelitian

Penelitian ini merupakan jenis penelitian hukum normatif. ${ }^{5}$

2. Metode Pendekatan

Dalam mencari kebenaran ilmiah, dalam penelitian ini menggunakan beberapa pendekatan dalam ilmu hukum, sebagai berikut:
a. Pendekatan
peraturan perundang-undangan
(statute approach).
b. Pendekatan konseptual (conceptual approach).

\section{Pembahasan}

\section{A. Pemaknaan Bencana Alam Nasional Dalam Penjelasan Pasal 2 Ayat 2 UU Tipikor.}

Sebelum lebih jauh menjelaskan pemaknaan bencana alam dalam Penjelasan Pasal 2 ayat 2 UU Tipikor tersebut, akan diuraikan terlebih dahulu pengertian dari bencana itu sendiri. Menilik ketentuan dalam Pasal 1 angka (1) Undang-undang Nomor 24 Tahun 2007 tentang

\footnotetext{
${ }^{5}$ Amiruddin dan Zainal Asikin. (2012). Metode Penelitian Hukum. Jakarta: Rajawali Pers. HIm. 118.
} 
Penanggulangan Bencana selanjutnya disebut UU Penanggulangan Bencana, dijelaskan pengertian bencana yakni "peristiwa atau rangkaian peristiwa yang mengancam dan mengganggu kehidupan dan penghidupan masyarakat yang disebabkan, baik oleh faktor alam dan/atau faktor non alam maupun faktor manusia sehingga mengakibatkan timbulnya korban jiwa manusia, kerusakan lingkungan, kerugian harta benda, dan dampak psikologis".

Lebih lanjut dijelaskan dalam angka (2) yang dimaksud dengan Bencana alam adalah "bencana yang diakibatkan oleh peristiwa atau serangkaian peristiwa yang disebabkan oleh alam antara lain berupa gempa bumi, tsunami, gunung meletus, banjir, kekeringan, angin topan, dan tanah langsor".

Sebagaimana yang telah disebutkan di atas, dalam UU Penanggulangan Bencana tidak secara eksplisit memberikan pengertian bencana alam nasional sebagaimana yang tertuang dalam Penjelasan Pasal 2 ayat 2 UU Tipikor. Frasa 'Bencana Alam Nasional' merupakan pengertian dari 'Keadaan Tertentu' sebagaimana termaktub dalam Pasal 2 ayat (2) UU Tipikor. Frasa 'Keadaan Tertentu' merupakan istilah lain dari 'Keadaan Darurat' atau 'Keadaan Bahaya'.

Menurut Jimly Asshiddiqie menulis dengan mengutip dari Black's Law Dictionary, secara terminologis 'Keadaan darurat' berkaitan dengan 'emergency doctrine' diartikan sebagai berikut: ${ }^{6}$

"Pertama, A legal principle exempting a person from the ordinary standard of reasonable, care if that person acted

\footnotetext{
${ }^{6}$ Jimly Asshiddiqie. (2008). Hukum Tata Negara Darurat. Jakarta: Rajawali Pers. HIm. 57.
}

instinctively to meet a sudden and urgent need for aid; Kedua, A legal principle by which consent to medical treatment in a dire situation is inferred when neither the patient not a responsible party can consent but a reasonable person waould do so; Ketiga, The principle that a police officer may conduct a search without a warrant if the officer has probable cause and reasonably beleieves that immediate action is needed to protect life or property".

Lebih lanjut Jimly mengartikan bahwa: pengertian yang pertama berkaitan dengan konsep "sudden-emergency doctrine" atau doktrin keadaan darurat tiba-tiba. pengertian yang kedua biasa dipakai di dunia kedokteran dan pelayanan medis, sedangkan pengertian yang ketiga berkenaan dengan persoalan 'emergency exception'. Pengertian yang mempunyai relevansi dengan persoalan hukum adalah pengertian yang pertama dan yang ketiga.

Di Indonesia, istilah yang digunakan dalam UUD 1945 yaitu: (i) keadaan bahaya; dan (ii) hal ikhwal kegentingan yang memaksa. Dalam pengertiannya yang praktis, keduanya menunjuk kepada persoalan yang sama, yaitu keadaan yang dikecualikan dari keadaan yang bersifat normal atau "state of exception".

Berdasarkan pengertian dalam Black's Law Dictionary sebagaimana dikutip oleh Jimly di atas, maka Bencana Alam merupakan keaadaan yang termasuk dalam pengertian yang pertama yakni keadaan darurat tiba-tiba. Keadaan darurat tiba-tiba dapat diartikan bahwa siapapun tidak dapat memprediksi kapan waktu akan terjadinya bencana tersebut. 
Isitilah Keadaan Tertentu disebutkan dalam Pasal 1 angka (1) Peraturan Presiden Nomor 17 Tahun 2018 tentang Penyelenggaraan Penanggulangan Bencana. Keadaan Tertentu adalah suatu keadaan dimana status Keadaan Darurat Bencana belum ditetapkan atau status Keadaan Darurat Bencana telah berakhir dan/atau tidak diperpanjang, namun diperlukan atau masih diperlukan tindakan guna mengurangi Risiko Bencana dan dampak yang lebih luas.

Dalam keadaan-keadaan tertentu demikian, maka negara melalui pemerintah maupun pemerintah daerah memiliki kewenangan untuk menetapkan status keadaan melalui ketetapannya. Dalam hal menetapkan status bencana menjadi "bencana alam nasional" maka itu mutlak menjadi kewenangan pemerintah pusat yakni Presiden.

Sebagaimana ditegaskan, Pasal 7 UU Penanggulangan Bencana menyatakan bahwa, Pemerintah memiliki kewenangan menetapkan status bencana nasional sebagaimana disebutkan dalam Pasal 7 (1) yakni :

"Wewenang Pemerintah dalam penyelenggaraan penanggulangan bencana meliputi: a. penetapan kebijakan penanggulangan bencana selaras dengan kebijakan pembangunan nasional; $b$. pembuatan perencanaan pembangunan yang memasukkan unsur-unsur kebijakan penanggulangan bencana; c. penetapan status dan tingkatan bencana nasional dan daerah...".

Lebih lanjut dalam ayat (2) disebutkan:

"Penetapan status dan tingkat bencana nasional dan daerah sebagaimana dimaksud pada ayat (1) huruf c memuat indikator yang meliputi: a. jumlah korban; b. kerugian harta benda; c. kerusakan prasarana dan sarana; d. cakupan luas wilayah yang terkena bencana; dan e. dampak sosial ekonomi yang ditimbulkan".

Dalam peraturan sebagaimana telah diuraikan di atas, Penulis sama sekali tidak menemukan pengertian apa yang dimaksud dengan "Bencana Alam Nasional" sebagaimana yang disebutkan dalam Penjelasan Pasal 2 ayat (2) UU Tipikor maupun UU Penanggulangan Bencana, melainkan hanya disebutkan syarat-syarat untuk dinyatakan dan ditetapkan suatu bencana menjadi bencana nasional oleh Presiden.

Menurut Tjahjo Kumolo, "suatu bencana dapat dinyatakan sebagai bencana nasional, yaitu pertama, jika pemerintah daerah (pemda) tidak beroperasi, tidak ada cara untuk memperoleh sumber daya nasional, dan jika ada peraturan atau undang-undang yang menghambat pelaksanaan tanggap darurat.". ${ }^{7}$

Berdasarkan uraian tersebut, Penulis berpendapat bahwa Masih terdapat ketidakpastian dalam persyaratan penentuan bencana nasional, terutama jumlah korban, kerugian harta benda dan dampak sosial ekonomi yang ditimbulkan oleh bencana. Oleh karena itu, pemerintah harus tegas menetapkan peraturan perundang-undangan terkait hal ini di kemudian hari.

\footnotetext{
${ }^{7}$ Nugraheny, Dian Erika. (2018). Tiga Syarat Penetapan Status Bencana Nasional. https://republika.co.id/berita/nasional/politik/18/08/20 /pdrkbt430-tiga-syarat-penetapan-status-bencananasional. 20 Agustus 2018, Diakses tanggal 25 Juni 2021.
} 


\section{B. Pengaturan Penegakan Sanksi Pidana Mati Bagi Pelaku Tindak Pidana Korupsi Di Waktu Bencana Alam Berdasarkan Pasal 2 Ayat 2 UU Tipikor.}

Sebagaimana telah ditulis di awal bahwa Haji Muhir seorang anggota DPRD Kota Mataram ditangkap oleh tim Kejaksaan Negeri Mataram. Penangkapan tersebut berkaitan dengan suap untuk rekonstruksi pasca gempa bumi untuk satuan pendidikan di Kota Mataram dan ditetapkan sebagai tersangka. Ia, didakwa oleh Jaksa Penuntut Umum dengan dakwaan alternatif yaitu Pertama Pasal 12 huruf e atau Kedua Pasal 12 huruf b, atau Ketiga Pasal 11 UU Tipikor. Singkatnya, Jaksa Penuntut Umum dalam tuntutannya menuntut terdakwa dengan Pasal 12 huruf e dan sanksi pidana selama 8 tahun penjara serta denda sebesar $\mathrm{Rp}$ 250.000.000 (dau ratus lima puluh juta rupiah), subsidair pidana kurungan selama 6 bulan. Berdasarkan hal tersebut, kemudian majelis Hakim menjatuhkan hukuman kepada terdakwa dengan pidana penjara selama 2 tahun dan denda sebesar Rp. 50.000.000,- (lima puluh juta rupiah) subsidair pidana kuruungan 2 bulan. ${ }^{8}$

Kasus sebagaimana diuraikan di atas tentu saja tidak sejalan dengan semangat pemberantasan korupsi dan undang-undang yang mengaturnya. Padahal jika mengacu pada pendapat Nonet dan Sleznick sebagaimana dikutip oleh Fenty U. Puluhulawa dkk bahwa9 "hukum harus benar-benar mensejahterakan masyarakat

\footnotetext{
8 Putusan Pengadilan Tindak Pidana Korupsi pada Pengadilan Negeri Mataram No: 23/Pid.sus.Tipikor/2018/PN Mtr.

9 Puluhulawa, F.U, J. Puluhulawa, M.G. Katili. (2020) "Legal Weak Protection of Personal Data in the 4.0 Industrial Revolution Era." Jambura Law Review. 2 (2). Universitas Negeri Gorontalo. HIm 182-200
}

dalam kepentingan yang lebih besar, bukan saja hanya untuk kepentingan mereka yang berkuasa," sehingga seharusnya, Penulis berpendapat dakwaan Jaksa Penuntut Umum menggunakan Pasal 2 ayat 2 UU Tipkor. Sebab itu sudah jelas dilakukan dalam keadaan tertentu yakni berkaitan dengan penanganan pasca bencana alam gempa bumi terjadi yang melanda pulau Lombok.

Pendapat yang berbeda dikemukakan oleh Ketut Sumedana sebagai Kepala Kejaksaan Negeri Mataram yang mengatakan bahwa:

"Penjatuhan hukuman mati kepada oknum anggota dewan tersebut tidak dapat diterapkan karena bencana alam gempa bumi yang melanda Provinsi Nusa Tenggara Barat khususnya Pulau Lombok bukanlah bencana alam nasional sesuai dengan ketentuan Pasal 2 ayat 2 UU Tipikor. Akan tetapi, itu nanti bisa menjadi unsur pemberat tuntutan..."10

Sanksi hukum pidana mati yang disebutkan tersebut merupakan salah satu jenis sanksi hukum dalam hukum pidana. Apabila menilik ketentuan di dalam Kitab Undang-Undang Hukum Pidana selanjutnya disingkat KUHP sesungguhnya masih banyak jenis sanksi hukum pidana yang dapat dijatuhkan kepada seseorang yang melakukan perbuatan melawan hukum pidana. Ditegaskan dalam ketentuan Pasal 10 KUHP, pidana terdiri atas: ${ }^{11}$

\footnotetext{
10 Sumedana, Ketut. (2018). Muhir Lolos dari Ancaman Hukuman Mati, Lombok Post, 19 September 2018, hlm. 27., Suharli. (2018). Jaksa Beberkan Dosa Muhir, Lombok Post, 17 Oktober 2018, hlm. 11.

11 Redaksi Sinar Grafika. (2013). KUHAP dan KUHP. Jakarta: Sinar Grafika. HIm. 5-6.
} 
a. Pidana pokok terdiri dari: 1) Pidana mati; 2) Pidana penjara; 3) Pidana kurungan; 4) Pidana denda; dan 5) Pidana tutupan.

b. Pidana Tambahan terdiri dari: 1) Pencabutan hak-hak tertentu; 2) Perampasan barang-barang tertentu; dan 3) Pengumuman putusan hakim.

Sementara Darwan Prints mengatakan bahwa UU Tipikor (Pasal 2, Pasal 3, Pasal 5 sampai dengan Pasal 14) mengatur hukuman pokok itu sebagai berikut: ${ }^{12}$

1. Pidana Mati;

2. Pidana Penjara;

a. Seumur hidup;

b. Sementara waktu;

3. Hukuman Denda.

Lebih jelasnya dapat dilihat dalam tabel berikut:

\begin{tabular}{|c|c|c|c|c|c|}
\hline \multicolumn{6}{|c|}{ HUKUMAN POKOK } \\
\hline \multirow{2}{*}{ NO } & \multirow{2}{*}{ PASAL } & \multicolumn{2}{|c|}{ PIDANA } & \multicolumn{2}{|c|}{ DENDA } \\
\hline & & MIN & MAKS & MIN & MAKS \\
\hline \multirow[t]{2}{*}{1} & \multirow[b]{2}{*}{2} & \multicolumn{2}{|c|}{$\begin{array}{c}\text { Seumur Hidup } \\
\text { atau }\end{array}$} & & \\
\hline & & $\begin{array}{l}4 \\
\text { Tahun }\end{array}$ & $\begin{array}{l}20 \\
\text { Tahun }\end{array}$ & $\begin{array}{l}200 \\
\text { Juta }\end{array}$ & $\begin{array}{l}1 \\
\text { Miliar }\end{array}$ \\
\hline \multirow[t]{2}{*}{2} & \multirow[b]{2}{*}{3} & \multicolumn{2}{|c|}{$\begin{array}{l}\text { Seumur Hidup } \\
\text { atau }\end{array}$} & & \\
\hline & & $\begin{array}{l}1 \\
\text { Tahun }\end{array}$ & $\begin{array}{l}20 \\
\text { Tahun }\end{array}$ & $\begin{array}{l}50 \\
\text { Juta }\end{array}$ & $\begin{array}{l}1 \\
\text { Miliar }\end{array}$ \\
\hline 3 & 5 & $\begin{array}{l}1 \\
\text { Tahun }\end{array}$ & $\begin{array}{l}5 \\
\text { Tahun }\end{array}$ & $\begin{array}{l}50 \\
\text { Juta }\end{array}$ & $\begin{array}{l}250 \\
\text { Juta }\end{array}$ \\
\hline 4 & 6 & $\begin{array}{l}3 \\
\text { Tahun }\end{array}$ & $\begin{array}{l}15 \\
\text { Tahun }\end{array}$ & $\begin{array}{l}150 \\
\text { Juta }\end{array}$ & $\begin{array}{l}750 \\
\text { Juta }\end{array}$ \\
\hline 5 & 7 & $\begin{array}{l}2 \\
\text { Tahun }\end{array}$ & $\begin{array}{l}7 \\
\text { Tahun }\end{array}$ & $\begin{array}{l}100 \\
\text { Juta }\end{array}$ & $\begin{array}{l}350 \\
\text { Juta }\end{array}$ \\
\hline 6 & 8 & 3 & 15 & 150 & 750 \\
\hline
\end{tabular}

12. Teguh Prasetyo. (2011). Hukum Pidana. Jakarta: Rajawali Pers. HIm. 120.

\begin{tabular}{|c|c|c|c|c|c|}
\hline & & Tahun & Tahun & Juta & Juta \\
\hline 7 & 9 & $\begin{array}{l}1 \\
\text { Tahun }\end{array}$ & $\begin{array}{l}5 \\
\text { Tahun }\end{array}$ & $\begin{array}{l}50 \\
\text { Juta }\end{array}$ & $\begin{array}{l}250 \\
\text { Juta }\end{array}$ \\
\hline 8 & 10 & $\begin{array}{l}2 \\
\text { Tahun }\end{array}$ & $\begin{array}{l}7 \\
\text { Tahun }\end{array}$ & $\begin{array}{l}100 \\
\text { Juta }\end{array}$ & $\begin{array}{l}350 \\
\text { Juta }\end{array}$ \\
\hline 9 & 11 & $\begin{array}{l}1 \\
\text { Tahun }\end{array}$ & $\begin{array}{l}5 \\
\text { Tahun }\end{array}$ & $\begin{array}{l}50 \\
\text { Juta }\end{array}$ & $\begin{array}{l}250 \\
\text { Juta }\end{array}$ \\
\hline 10 & 12 & $\begin{array}{l}4 \\
\text { Tahun }\end{array}$ & $\begin{array}{l}20 \\
\text { Tahun }\end{array}$ & $\begin{array}{l}200 \\
\text { Juta }\end{array}$ & $\begin{array}{l}1 \\
\text { Miliar }\end{array}$ \\
\hline 11 & 13 & $\ldots$. & $\begin{array}{l}3 \\
\text { Tahun }\end{array}$ & $\ldots$. & $\begin{array}{l}150 \\
\text { Juta }\end{array}$ \\
\hline 12 & 21 & $\begin{array}{l}3 \\
\text { Tahun }\end{array}$ & $\begin{array}{l}12 \\
\text { Tahun }\end{array}$ & $\begin{array}{l}150 \\
\text { Juta }\end{array}$ & $\begin{array}{l}600 \\
\text { Juta }\end{array}$ \\
\hline 13 & 22 & $\begin{array}{l}3 \\
\text { Tahun }\end{array}$ & $\begin{array}{l}12 \\
\text { Tahun }\end{array}$ & $\begin{array}{l}150 \\
\text { Juta }\end{array}$ & $\begin{array}{l}600 \\
\text { Juta }\end{array}$ \\
\hline 14 & 23 & $\begin{array}{l}1 \\
\text { Tahun }\end{array}$ & $\begin{array}{l}6 \\
\text { Tahun }\end{array}$ & $\begin{array}{l}50 \\
\text { Juta }\end{array}$ & $\begin{array}{l}300 \\
\text { Juta }\end{array}$ \\
\hline 15 & 24 & $\ldots$. & $\begin{array}{l}3 \\
\text { Tahun }\end{array}$ & $\ldots$. & $\begin{array}{l}150 \\
\text { Juta }\end{array}$ \\
\hline
\end{tabular}

Sumber: Darwan Prints, 2002.13

Lanjut Darwan Prints, selain terdapat pidana pokok dalam KUHP disitu juga diatur mengenai pidana tambahan. Dalam ketentuan Pasal 10 huruf b KUHP juncto Pasal 35 KUHP tentang Pencabutan hak-hak tertentu seperti:

a. Hak memegang jabatan pada umumnya atau jabatan yang tertentu;

b. Hak memasuki Tentara Nasional Indonesia;

c. Hak memilih dan dipilih dalam pemilihan yang diadakan berdasarkan aturan-aturan umum;

d. Hak menjadi penasihat (readsman) atau pengurus menurut hukum, hak menjadi wali, wali pengawas,

\footnotetext{
${ }^{13}$ Darwan Prints, Loc. cit.
} 
pengampu atau pengampu pengawas atas anak yang bukan anak sendiri;

e. Hak menjalankan kekuasaan bapak, menjalankan perwalian atau pengampuan atas anak sendiri;

f. Hak menjalankan pekerjaan yang ditentukan. ${ }^{14}$

Pemberian pidana mati terhadap para koruptor di Indonesia belum pernah dilakukan di Indonesia selama berlakunya Undang-undang Korupsi ini, bahkan terhadap sebuah kasus korupsi yang dilakukan oleh Ahmad Sidik Mauladi Iskandardinata Alias Dicky Iskandardinata, hakim tidak mengabulkan tuntutan Jaksa/Penuntut Umum. Kasus yang dilakukan Ahmad Sidik Mauladi Iskandardinata Alias Dicky Iskandardinata tersebut, Jaksa/Penuntut Umum meminta Hakim untuk memberikan hukuman mati terhadap terdakwa pasalnya terdakwa yang telah terbukti bersalah melakukan Tindak Pidana Korupsi sebagaimana diatur dalam pasal 2 ayat (2) Juncto pasal 18 Undang-Undang Republik Indonesia Nomor 31 Tahun 1999 sebagaimana diubah dan ditambah dengan Undang-Undang Nomor 20 tahun 2001 Juncto pasal 55 ayat (1) ke-1 juncto pasal 64 ayat (1) KUHP. Putusan Pengadilan Negeri Jakarta Selatan No. 114/Pid. B/2006/PN. Jak. Sel. Tanggal 20 Juni 2006 tidak mengabulkan tuntutan

14 Darwan Prints. (2002). Pemberantasan Tindak Pidana Korupsi. Bandung: PT. Citra Aditya Bakti. Hlm. 70-72.
Jaksa/Penuntut Umum, tetapi hanya menghukum terdakwa seumur hidup. ${ }^{15}$

Putusan tersebut memberikan preseden yang kurang baik dalam penegakan hukum di Indonesia khususnya pemberantasan tindak pidana korupsi. Menjatuhkan pidana yang seberatberatnya untuk memberikan efek jera kepada pelaku korupsi belum terlihat benar-benar dilakukan, karena untuk mengurangi terjadinya korupsi atau menghentikan terjadinya tindak pidana korupsi ini diperlukan keseriusan dari pemerintah dalam hal ini adalah aparat penegak hukum. ${ }^{16}$

Hukuman pidana mati, menurut Pasal 2 ayat (2) UU Tipikor yang dapat dijatuhkan kepada seseorang yang melakukan perbuatan melawan hukum tindak pidana korupsi di waktu bencana alam masih menimbulkan ketidakpastian hukum yang disebabkan karena tidak singkronnya bunyi ketentuan Pasal 2 ayat 2 dengan Penjelasan pasal tersebut, sehingga cenderung pasal tersebut menjadi "mandul" atau "pasal karet" yang tidak akan pernah hukuman mati tersebut dapat akan dijatuhkan kepada pelaku tindak pidana korupsi di waktu tersebut. Terlebih lagi dalam Pasal 2 ayat 2 tegas disebutkan frasa "dapat dijatuhkan".

Kata "dapat" dalam peraturan perundang-undangan memiliki arti ganda yakni dalam arti positif dan negatif. Dalam artinya yang positif kata 'dapat' berarti bisa, sanggup, mampu, boleh, mungkin. Sedangkan dalam artinya yang negatif itu berarti tidak harus. Demikian ditegaskan

15 Muhammad Arif Pribadi, dkk.(Tanpa Tahun). "Eksistensi Pidana Mati Dalam Tindak Pidana Korupsi Terkait Pembaharuan Hukum Pidana Di Indonesia”. Fakultas Hukum Universitas Brawijaya, Malang. HIm. 4. ${ }^{16}$ Ibid. 
dalam Putusan MK No. 25/PUU-XIV/2016 yang melakukan pengujian Pasal 2 ayat (1) dan Pasal 3 UU Tipikor secara lengkap dikutip sebagai berikut: ${ }^{17}$

"Bahwa dalam Kamus Besar Bahasa Indonesia kata "dapat" antara lain bermakna: "mampu”, "sanggup", "bisa", "boleh", serta "mungkin". Berdasarkan makna bahasa tersebut kata "dapat" tidak memiliki makna yang pasti. Dari segi bahasa, rumusan frasa "dapat" merugikan keuangan atau perekonomian negara dalam Pasal 2 ayat (1) dan Pasal 3 UU Tipikor tersebut bisa bermakna: a) merugikan keuangan negara; b) "mungkin" merugikan keuangan negara; c) "potensial" merugikan keuangan negara; d) "tidak harus" merugikan keuangan negara yang nyata."

Dengan berdasarkan pendapat di atas, maka kata "dapat dijatuhkan" dalam Pasal 2 ayat (2) tersebut memiliki makna bahwa di mana para pelaksana penegakan hukum tidak harus menerapkan ketentuan pidana mati atau dalam arti lain yakni pidana mati menjadi sanksi alternatif untuk diterapkan kepada para pelaku tindak pidana korupsi di waktu bencana alam terjadi.

Demikian diperkuat juga melalui Putusan Mahkamah Konstitusi Nomor:23/PUU-V/2007 dalam pertimbangan hukumnya sebagaimana dikutip oleh Djernih Sitanggang yakni:

\footnotetext{
${ }^{17}$ Putusan Mahkamah Konsitusi Nomor 25/PUUXIV/2016, hlm. 95. Lanjut dalam Putusan MK tersebut, MK membatalkan ketentuan kata "dapat" dalam Pasal 2 ayat (1) dan Pasal 3 UU Tipikor dan menyatakan bertentangan dengan Undang-Undang Dasar Negara Republik Indonesia Tahun 1945 dan tidak mempunyai kekuatan hukum mengikat.
}

"Bahwa dalam rangka pembaharuan hukum pidana nasional dan harmonisasi peraturan perundangundangan, maka perumusan, penerapan, maupun pelaksanaan pidana mati dalam sistem peradilan pidana di Indonesia hendaklah memperhatikan dengan sungguhsungguh hal berikut: 1) Pidana mati bukan lagi merupakan pidana pokok, melainkan sebagai pidana yang bersifat khusus dan alternatif; 2) Pidana mati dapat dijatuhkan dengan masa percobaan selama 10 (sepuluh) tahun yang apabila terpidana berkelakuan terpuji dapat diubah dengan pidana penjara, seumur hidup atau selama 20 (dua puluh) tahun; 3) Pidana mati tidak dapat dijatuhkan terhadap anak-anak yang belum dewasa; 4) Eksekusi pidana mati terhadap perempuan hamil dan seseorang yang sakit jiwa ditangguhkan sampai perempuan hamil tersebut melahirkan dan terpidana yang sakit jiwa tersebut sembuh". 18

Menurut Monang Siahaan sebagaimana dikutip oleh Oksidelfa Yanto mengungkapkan bahwa:

"Satu-satunya cara untuk menanggulangi masalah korupsi yaitu dengan memberikan hukuman seberatberatnya, salah satunya yaitu dengan diberikan hukuman mati. Hanya saja dalam pelaksanaannya, pada umumnya hampir tidak ada Hakim yang menjatuhkan pidana mati karena dikaitkan dengan alasan yang

\footnotetext{
18 Djernih Sitanggang. (2018). Kepastian Hukum Masa Tunggu Eksekusi Pidana Mati. Bandung: Pustaka Reka Cipta, HIm. 10.
} 
memberatkan maupun meringankan dan faktor meringankannya jauh lebih dominan dilihat dari batas hukuman tertinggi, pendidikan, dan lain-lain". 19

Oleh karena itu, Penulis berpendapat bahwa hukuman pidana mati kepada para pelaku tindak pidana korupsi di waktu terjadinya bencana alam tidak lebih hanya sebagai pasal untuk menakuti para pelaku ${ }^{20}$ dan sangat besar berpotensi tidak akan pernah terjadi di Indonesia. Pertama, pidana mati merupakan pidana alternatif; kedua, antara bunyi pasal dan ketentuan penjelasan tidak singkron; ketiga, tidak ada pengaturan jelas terkait dengan nominal batas maksimum dan minimum uang yang dikorupsi.

\section{PENUTUP}

\section{Kesimpulan}

Berdasarkan uraian dalam
pembahasan di atas, dapat ditarik
kesimpulan sebagai berikut:

1. Pemaknaan "bencana alam nasional" tidak ada diberikan pengertian secara terminologis melainkan hanya syarat-syarat sebuah bencana ditetapkan menjadi bencana nasional, antara lain: Pertama, jika pemerintah daerah (pemda) tidak berfungsi.. Kedua, tidak ada akses terhadap sumber daya nasional. Ketiga, bila ada regulasi atau peraturan

19 Yanto, Oksidelfa. (2017). "Penjatuhan Pidana Mati Pelaku Tindak Pidana Korupsi Dalam Keadaan Tertentu", Jurnal Legislasi Indonesia, 14 (1): 49-56. Universitas Pamulang.

20 Edi Yuhermansyah dan Zaziratul Fariza. (2017). "Pidana Mati Dalam UNdang-Undang Tindak Pidana Korupsi”, Jurnal Legitimasi, 6 (1): 156-174. perundangan yang menghambat pelaksanaan tanggap darurat.

2. Pengaturan sanksi hukum pidana mati bagi pelaku tindak pidana korupsi sebagaimana ketentuan Pasal 2 ayat (2) UU Tipikor khususnya yang terjadi di waktu bencana alam nasional tidak lebih hanya untuk membuat "takut" dan kecil kemungkinan dapat diterapkan karena: Pertama, pidana mati merupakan pidana alternatif; Kedua, antara bunyi pasal dan ketentuan penjelasan tidak singkron; Ketiga, tidak ada pengaturan jelas terkait dengan nominal batas maksimum dan minimum uang yang dikorupsi.

\section{Saran}

Adapun saran dari hasil kajian ini adalah::

1. Pemerintah harus menetapkan batas maksimum dan minimum uang yang dikorupsi menjadi dasar pengenaan hukuman mati.

2. Penegak hukum harus berani dan tegas dalam memberlakukan hukum tindak pidana korupsi di waktu bencana alam.

\section{REFERENSI}

\section{Buku}

Asikin, Zainal dan Amiruddin. (2012). Metode Penelitian Hukum. Jakarta: Rajawali Pers.

Asshiddiqie, Jimly. (2008). Hukum Tata Negara Darurat. Jakarta: Rajawali Pers. --------, Pengantar Ilmu Hukum Tata Negara. Jakarta: Rajawali Pers, 2010. 
Djatmiko, Purwo, (2012). Kamus Lengkap Bahasa Indonesia. Surabaya: Anugerah. Prasetyo, Teguh, (2011). Hukum Pidana. Jakarta: Rajawali Pers.

Prints, Darwan. (2002). Pemberantasan Tindak Pidana Korupsi. Bandung: PT. Citra Aditya Bakti.

Redaksi Sinar Grafika, (2013). KUHAP dan KUHP. Jakarta: Sinar Grafika.

Sitanggang, Djernih. (2018). Kepastian Hukum Masa Tunggu Eksekusi Pidana Mati. Bandung: Pustaka Reka Cipta.

\section{Jurnal}

Puluhulawa, F.U, J. Puluhulawa, M.G. Katili. (2020). "Legal Weak Protection of Personal Data in the 4.0 Industrial Revolution Era." Jambura Law Review. 2 (2). Universitas Negeri Gorontalo

Yanto, Oksidelfa. (2017). "Penjatuhan Pidana Mati Pelaku Tindak Pidana Korupsi Dalam Keadaan Tertentu", Jurnal Legislasi Indonesia, 14 (1): 49-56., Universitas Pamulang.

Yuhermansyah, Edi dan Zaziratul Fariza. (2017). "Pidana Mati Dalam UndangUndang Tindak Pidana Korupsi", Jurnal Legitimasi, 6 (1): 156-174.

\section{Makalah}

Arif Pribadi, Muhammad dkk. Tanpa Tahun. Eksistensi Pidana Mati Dalam Tindak Pidana Korupsi Terkait Pembaharuan Hukum Pidana Di Indonesia. Makalah. Malang: Fakultas Hukum Universitas Brawijaya.

\section{Peraturan Perundang-Undangan}

Undang-Undang Nomor 24 Tahun 2007 Tentang Penanggulangan Bencana. Undang-Undang Nomor 20 Tahun 2001 Tentang Perubahan Atas UndangUndang Nomor 31 Tahun 1999
Tentang Pemberantasan Tindak Pidana Korupsi..

\section{Putusan Pengadilan}

Putusan Mahkamah Konsitusi Nomor 25/PUU-XIV/2016 Tentang Pengujian Undang-Undang Nomor 20 Tahun 2001 tentang Perubahan Atas UndangUndang Nomor 31 Tahun 1999 Tentang Pemberantasan Tindak Pidana Korupsi Terhadap UndangUndang Dasar Negara Republik Indonesia Tahun 1945.

Putusan Pengadilan Tindak Pidana Korupsi pada Pengadilan Negeri Mataram No: 23/Pid.sus.Tipikor/2018/PN Mtr.

\section{Media Massa}

Makhtul, Aris. 2018. "HM Terancam Dicoret dari Daftar Bacaleg”. Suara NTB, 15 September 2018.

Suharli. 2018. "Ditangkap di Depan Anak". Lombok Post, 15 September 2018.

2018. "Muhir Lolos dari Ancaman Hukuman Mati”. Lombok Post, 19 September 2018.

2018. "Jaksa Beberkan Dosa Muhir". Lombok Post, 17 Oktober 2018.

\section{Website}

Nugraheny, Dian Erika. (2018 Agustus 20). Tiga Syarat Penetapan Status Bencana Nasional. https://republika.co.id/berita/nasion al/politik/18/08/20/pdrkbt430-tigasyarat-penetapan-status-bencananasional. 20 Agustus 2018, Diakses tanggal 25 Juni 2021.

Zulfikar, Satria. (2018 April 14). Minta Jatah Uang Rehab Gempa Loombok Politikus Golkar Ditangkap. https://www.viva.co.id/berita/nasio nal/1074726-minta-jatah-uangrehab-gempa-lombok-politikus- 
golkar-ditangkap. 14 September 2018, Diakses tanggal 25 juni 2021.

Liputan 6.com. (2018 September 17), Petugas Intai Muhir Selama 2 Bulan Terkait

KorupsiPembangunanSekolahdiLombo k,https://www.liputan6.com/news/r ead/3645799/petugas-intai-muhirselama-2-pekan-terkait-korupsipembangunan-sekolah-di-lombok. 17 september 2018, Diakses tanggal 25 juni 2021, 